\title{
SENSE RELATIONS IN LANGUAGE LEARNING
}

\author{
Menik Winiharti \\ English Department, Faculty of Language and Culture, Bina Nusantara University, \\ Jln. Kemanggisan Ilir III No. 45, Kemanggisan/Palmerah, Jakarta Barat 11480
}

\begin{abstract}
Studying a language cannot be separated from studying the meaning of that language because when one is learning a language he/she is also learning the meaning of the language. The meaning of a language can be seen from its relation between words, i.e. the sense of one word is related to the sense of another. In this case there are two major groups of sense relations. The first group is the sense relations with regard to the sameness as synonymy. The second one is the sense relations of oppositeness as antonymy. This paper is to discuss both kinds of sense relations since they are important in semantics.
\end{abstract}

Keywords: sense relations, synonymy, antonymy

\begin{abstract}
ABSTRAK
Mempelajari sebuah bahasa tidak dapat terlepas dari mempelajari makna bahasa itu karena ketika seseorang sedang belajar suatu bahasa, dia juga belajar maknanya. Makna sebuah bahasa dapat dilihat dari segi hubungan makna antar kata, yaitu makna sebuah kata dihubungkan dengan makna kata yang lain. Dalam hal ini ada dua kelompok besar berkenaan dengan hubungan makna. Yang pertama adalah hubungan kesamaan makna seperti sinonim. Yang kedua adalah hubungan pertentangan makna seperti antonim. Makalah ini membahas kedua hubungan makna tersebut karena hal itu penting dalam studi semantik.
\end{abstract}

Kata kunci: hubungan makna, sinonim, antonim 


\section{INTRODUCTION}

The meaning of languages is always interested to study, since when we learn or use the language it deals with its meaning. The meaning of a language is often seen from the relation of a word with other word. Hurford et. al. (2007, p. 29) states that the sense of an expression is a semantic relationship of an expression with other expressions in the language. This paper is to discuss the notions of sense relations between words, i.e. sense relations of inclusion and sense relations of exclusion.

\section{RESEARCH METHODS}

This article was based on library research. Some of experts' concepts and researches were analyzed and compiled in this article.

\section{RESULTS AND DISCUSSION}

\section{Sense Relations}

Kreidler (1998, p.303) defines sense relations as "the relations of meaning between words, as expressed in synonymy, hyponymy, and antonymy." Thus, sense relations can be seen from the similarity of meaning as in synonymy, the inclusion of meaning as in hyponymy, and the oppositeness of meaning as in antonymy. Whereas Cruse (2004, p.148) classifies sense relations into two classes, i.e. those that express identity and inclusion between word meanings and those that express opposition and exclusion. The first class discusses the sense relations between words whose meanings are similar or included in other ones. The second class discusses the sense relations between words whose meaning are opposite or excluded from other words.

\section{Sense Relations of Inclusion and Identity}

The discussion in this part includes the notions of synonymy, homonymy, polysemy, and hyponymy.

\section{Synonymy}

Richards and Schmidt (2002, p.533) define synonymy as "a word which has the same sense, or nearly the same as another word.” Take a look at these sentences.

The street is very wide/broad

In these examples, each pair of the italic words is synonymous. In (1) wide and broad are replaceable each other and the meaning of the sentence remains the same. Similarly, deep and profound in (2) can replace each other and the meaning of the sentence does not change. However, there are words that synonymous in one context but not in the other one, as in the following:

The student speaks with a broad British accent

* The student speaks with a wide British accent.

The scouts are crossing a very deep river

* The scouts are crossing a very profound river. 
The pair of wide and broad in (3) is not synonymous since wide cannot substitute broad in that context. Similarly, deep and profound are not synonymous since profound cannot be used in that context to replace deep.

To conclude, a pair of words can be synonymous in one context but may be not synonymous in other contexts.

\section{Homonymy and Polysemy}

Richards and Schmidt (2002, p.241) define homonymy as "words which are written in the same way and sound alike but which have different meanings.”

Our house is on the west bank of the river

I want to save my first salary in the bank

Bank in (5) and (6) are homonyms. They are written in the same way and sound alike, but their meanings are different. In (5) bank refers to 'the side of a river and the land near it', while in (6) it is 'an organization that provides various financial services'.

In the ball the prince invites Cinderella to dance

In (7) and (8) ball are homonyms. They are spelled and pronounced in the same way but have different meanings. Ball in (7) means 'a large formal party with dancing', whereas in (8) it refers to 'a round object used for throwing, hitting or kicking in games and sports'.

It is sometimes difficult to distinguish homonymy from polysemy because the later also deals with a pair of words which are written and pronounced in the same way. Richards and Schmidt (2002, p.406) define Polysemy as "word having two or more closely related meanings."

The sun is very bright today

In (9) bright means 'shining' and in (10) it means 'intelligent'. The related meanings are that the sense of bright student brings the sense of shine in that a bright student usually shines his/her intelligence.

The same case occurs in sentence (11) and (12). Each of the sentences contains earth which refers to our planet as in (11) and in (12) it means soil. Both contain the sense of land, i.e. earth as land, not sky and earth as soil, not water.

Let us save our earth

The children filled the hole with soft earth

12

Then a question comes up as the notion of homonymy and polysemy may look similar. What is the difference between homonymy and polysemy? According to Hurford et.al. (2007, p. 130) the distinction between homonymy and polysemy deals with the closeness or relatedness of the senses of between words. Thus, homonymy deals with different meanings, whereas polysemy deals with related meanings.

\section{Hyponymy}

According to Richards and Schmidt (2002, p.243), hyponymy is "a relationship between two words, in which the meaning of one of the words includes the meaning of the other word." It can be 
seen in the relation between cat and animal, pigeon and bird, orchid and flower. Cat is said to be a hyponym of animal, pigeon a hyponym of bird, and orchid a hyponym of flower. On the other hand, animal is said to be the superordinate (also called hyperonym) of cat, bird the superordinate of pigeon, and flower the superordinate of orchid. Such relation is often described as one of inclusion. "From the extensional point of view, the class denoted by the superordinate term includes the class denoted by the hyponym as a sub-class." (Cruse, 2004, p. 148). Hence, the class of flower includes the class of orchid as one of its subclasses. Additionally, flower is the general term that includes orchid and other types of flowers such as rose and tulip. The relations among orchid, rose, and tulip are called co-hyponyms.

The sense relations of inclusion, in this case hyponymy, can be seen in the following diagram:

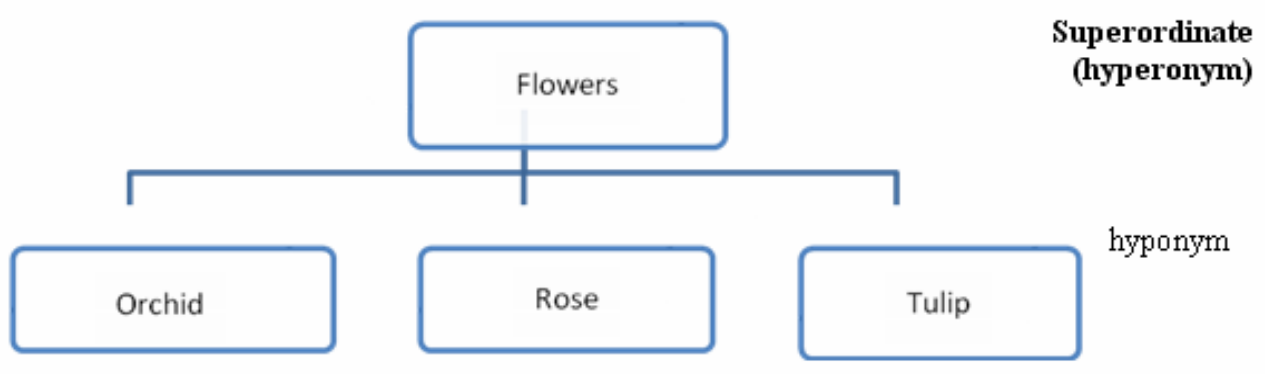

Figure 1 Hyponymy

\section{Taxonymy}

Cruse (2004, p. 150) states that "taxonymy is a sub-type of hyponymy.” In his other book (1995, p.137) he states, "A useful diagnostic frame for taxonymy is: An $X$ is a kind/type of $Y$ ". Take a look at these pairs:

\section{$\mathrm{X} \quad \mathrm{Y}$}

Poodle : dog

Orchid : flower

A poodle is a type of dog

Banana : fruit

In these examples, 'each of $\mathrm{X}$ is a hyponym of $\mathrm{Y}$ '. But what distinguishes taxonymy from hyponymy? Cruse (2004, p. 150) states that ". . . a taxonym must engage with the meaning of its superordinate in a particular way, by further specifying what is distinctive about it.”

? A puppy is a type of dog.

? A teenager is a type of person

The key distinctive characteristics of a poodle is being 'small and having thick curling hair', and poodle makes it more defined as compared to other types of dog as dalmatian and bulldog. On the contrary, puppy does not specify the characteristics of dog as compared to several types of dog as poodle, dalmatian, and bulldog. The key distinctive characteristics of puppy in the class of dog is that it only indicates a 'young dog'. Therefore, puppy cannot be said to be a 'type' of dog.

Similarly, teenager in sentence (17) is not a type of person since it refers to a person who is between 13 and 19 years old. 


\section{Sense Relations of Exclusions and Opposition}

The relations of senses between words can be seen from their oppositeness or that the sense of a word is excluded from the sense of another. The discussion includes antonymy, complementaries, reversives, converses, and incompatibility.

\section{Antonymy}

According to Cruse (1995, p.204), antonymy is "exemplified by such pairs as long: short, fast: slow, easy: difficult, good: bad, hot: cold." There are three types of antonyms (Cruse, 2004, p.164-5; 1995, p.204-5):

\section{- Polar Antonyms}

This type of oppositeness can be easily modified with degree modifiers such as very, rather, quite, slightly, extremely, and the like. Example:

The essay is very long

The test is quite easy

His performance is not extremely bad

They can also be applied in the comparative or superlative degree as in easy - easier - easiest; bad - worse - worst. Other characteristic of this antonym is that a normal how-question can be applied only to one member of a pair. Example:

How long is your essay?

But not: ?How short is your essay?

\section{- Equipollent Antonyms}

This type of antonym refer to subjective sensations as hot: cold, bitter: sweet, painful: pleasurable, or emotions as happy: sad, proud of: ashamed of. Other characteristics is that normal how-question can be applied to both terms of the pair as in (22) and (23).

How hot is the weather?

How cold is the weather?

- Overlapping Antonyms

Cruse (2004, p.166) states that "All overlapping antonym pairs have an evaluative polarity as part of their meaning as good: bad, kind: cruel, clever: dull, pretty: plain, polite: rude." In this case how-question can be applied to both terms of the pairs, but one term yields a neutral question and the other one a committed question. Example:

How good is the performance?

How bad is your test score?

Other semanticists as Hurford et. al. (2007) and Saeed (2005) name this classification of antonyms as one single notion: 'gradable antonyms'.

\section{Complementaries}

Cruse (2004, p. 163) states, "Complementaries constitute a very basic form of oppositeness and display inherent binarity in perhaps its purest form.” In his other book (1995, p. 198-9) he points out that "The essence of a pair of complementaries is that between them exhaustively divide some conceptual domain into two mutually exclusive compartments, so that what does not fail into one of the compartments must necessarily fall into the other.” The pairs of true: false, dead: alive, open: shut, 
hit: miss (a target), pass: fail (an examination) are all complementaries. Ordinarily, the complementary adjectives cannot be used with the degree modifiers as in gradable antonyms. Therefore, it is odd to say very true, rather dead, and extremely shut. Moreover, they are not applied in the comparative and superlative degrees. Hence it is odd to say truer, truest; deader, deadest. In addition, "Complementarity can be given a strict logical definition: $F(X)$ entails and is entailed by not $-F(Y)$." (Cruse, 2004, p.164). Correspondingly, Saeed (2005, p. 66) states, "the negative of one implies the positive of the other.” Take a look at the following sentences:

The door is open

The door is not shut

John is dead

John is not alive

The pairs of open - shut and dead - alive are complementaries. The sense of sentence (27) entails and is entailed by the sense of sentence (28). Likewise, the sense of (29) entails and is entailed by the sense of (30).

There is another notion to refer to complementaries. Hurford et. al. (2007), Saeed (2005) and Kreidler (1998) call it binary antonyms.

\section{Reversives}

"Reversives belong to a broader category of directional opposites which include straight forward directions such as up: down, forwards: backwards, into: out of, north: south, and extremes along some axis, top: bottom. ..” (Cruse, 2004, p. 166) Reversives also denote movement in opposite directions, such as come: go, go: return, rise: fall. In addition, Saeed (2005, p.67) who call it reverses, the notion can also describe any process that can be reversed as inflate: deflate, expand: contract, fill: empty, and knit: unravel.

\section{Converses}

Cruse (2004, p. 167) suggests that "Converses are also often considered to be a subtype of directional opposite." Above: below, own: belong to, in front of: behind, before: after are pairs of converses. Hence, if $A$ is above $B$, then $B$ is below $A$. The similar cases happen to the pair of sentence (31) and (32), and the pair of sentence (33) and (34).

The new car belongs to me $\quad 31$

I own the new car 32

$\begin{array}{ll}\text { President election is held after legislative election } & 33\end{array}$

Legislative election is held before president election $\quad 34$

\section{Incompatibility}

"Incompatibles are terms which denote classes which are disjunct, i.e. they have no members in common. Hence, if something is a mouse, then it is not a dog, horse, or elephant: nothing in the world can belong simultaneously to the class of mice and the class of dogs.” (Cruse, 2004, p. 161) Incompatibility occurs in the case of co-hyponyms. Some sub-classes belong to one superordinate but their relation is incompatible.

Superordinate

Flower

Sports

Sibling
Incompatible Hyponyms

rose, tulip, orchid

football, tennis, basketball

sister, brother 
From the set of terms denoting kinds of flower, it can be said that if it is a rose, then it is not an orchid or tulip. If it is a football, then it is not a tennis or basketball. Likewise, if it is a sister, it is not a brother.

\section{CONCLUSION}

Sense relations are one of important elements with regard to learning semantics, the study of language meaning. The sense of a word can be understood from its similarity with other words. On the other hand, it can also be learned from its oppositeness with other words.

\section{REFERENCES}

Cruse, D.A. (1995). Lexical Semantics. Cambridge: Cambridge University Press.

(2004). Meaning in Language: An Introduction to Semantics and Pragmatics. $2^{\text {nd }}$ edn. Oxford: Oxford University Press.

Hurford, J.R., B. Heasley, \& M.B. Smith. (2007). Semantics: A Coursebook. $2^{\text {nd }}$ edn. Cambridge: Cambridge University Press.

Kreidler, Charles W. (1998). Introducing English Semantics. London: Routledge.

Richards, J.C. \& R. Schmidt. (2002). Longman Dictionary of Language Teaching and Applied Linguistics. 3nd edn. London: Pearson Education Limited.

Saeed, John L. (2005). Semantics. $2^{\text {nd }}$ edn. Oxford: Blackwell Publishing.

Wehmeier, Sally. (ed) (2005). Oxford Advanced Learner's Dictionary. $7^{\text {th }}$ edn. Oxford: Oxford University Press. 